\title{
BIOLOGICAL AND MOLECULAR DIFFERENTIATION BETWEEN CORONAVIRUSES ASSOCIATED WITH NEONATAL CALF DIARRHOEA AND WINTER DYSENTERY IN ADULT CATTLE
}

\author{
G. Millane, L. Michaud, and S. Dea \\ Centre De Recherche en Virologie \\ Institut Armand Frappier \\ Universite Du Québec \\ Laval, Québec \\ Canada, H7N 4Z3
}

\begin{abstract}
Cytopathic coronaviruses were isolated in HRT-18 cells from bloody faecal samples collected from cows in Québec dairy herds with classical winter dysentery (WD). The formation of polykaryons in the infected cell cultures was found to be dependent on the presence of trypsin in the medium. Virus identification was confirmed by indirect immunofluorescence and indirect protein A-gold immunoelectron microscopy using rabbit hyperimmune serum, as well as monoclonal antibodies directed against the spike (S) and hemagglutinin-esterase (HE) glycoproteins of the prototype Mebus strain of bovine coronavirus (BCV-Meb). Four WD isolates differed from BCV-Meb by their ability to agglutinate rat erythrocytes at 4 and $37^{\circ} \mathrm{C}$, their higher receptor destroying enzyme activity, but lower acetylesterase activity. The WD isolates were serologically indistinguishable from the reference BCV-Meb strain by virus neutralization and Western immunoblotting, but could be differentiated by hemagglutination-inhibition. Sequence analysis of the PCR-amplified HE gene of a plaque-purified WD isolate (BCQ-2590) revealed sufficient number of nucleotide and amino acid substitutions which may explain this antigenic variability.
\end{abstract}

\section{INTRODUCTION}

Bovine coronavirus is known to cause significant economic losses throughout the world. It is an enteric virus which multiplies in the differentiated enterocytes of the small 
intestine and colon, causing severe diarrhoea in neonatal calf and chronic shedding in adult cattle. ${ }^{1,2}$ Some recent reports have suggested that $\mathrm{BCV}$ also possesses a tissue tropism to the upper respiratory tract of calf causing pneumonia ${ }^{3}$. BCV is also associated to acute enteric infection in adult cattle during the winter season. The disease, known as winter dysentery (WD), is clinically characterized by an explosive apparition of acute diarrhoea in adult dairy and beef cattle, with dark bloody liquid diarrhoea, accompanied by decreased milk production and variable depression and anorexia ${ }^{4}$. The disease spreads rapidly to animal of all ages causing high morbidity but low mortality.

Although the etiological agent has not been conclusively identified, early investigation attributed the disease to Campylobacter fetus subspecies jejuni ${ }^{5}$ but recent reports have described coronavirus particles in the faeces of WD affected cattle ${ }^{2,4,6}$. The coronavirus identified were isolated in cell cultures and shown to be serologically related to the BCV-Meb strain?.

$\mathrm{BCV}$ is a well characterized hemagglutinating coronavirus. The viral particle is mostly spherical, enveloped and displays a double fringe of projections ${ }^{8,9}$. The viral genome consists of a large single-stranded RNA with positive polarity, approximately $30 \mathrm{~kb}$ in length, and encodes four major structural proteins: the nucleocapsid protein $(\mathrm{N})$, the integral membrane protein $(\mathrm{M})$, the spike glycoprotein $(\mathrm{S})$ and the hemagglutinin/esterase glycoprotein $(\mathrm{HE})$ which is associated to the acetylesterase activity $(\mathrm{AE})^{9,10}$.

Although WD isolates can be distinguished for their pathogenicity, several studies using different methods based on monoclonal and/or polyclonal antibodies ${ }^{4,7}$, have shown that they are antigenically related to the BCV-Meb strain. However, possible antigenic difference between them was suggested ${ }^{4}$ on the basis of virus neutralisation (VN). But there is still some controversy as to the existence of distinct BCV serotypes ${ }^{4,11,12}$.

The purpose of this study was to characterize BCV strains isolated in cell cultures from bloody faecal samples of the WD affected cattle, in comparison to reference strains of neonatal calf diarrhoea in Québec (Canada). The cytopathogenicity on HRT-18 cells, infectivity titers, enzymatic activities and serological crossreactivities of Québec WD isolates were compared to those of the reference BCV-Meb strain. The HE gene of a Québec WD and two NCD isolates were also sequenced and their deduced amino-acid sequences were compared.

\section{METHODOLOGY}

The prototype Mebus strain of $\mathrm{BCV}^{8}$, and the $67 \mathrm{~N}$ strain of the porcine hemagglutinating encephalomyelitis virus (HEV) were obtained from the American Type Culture Collection (ATCC VR-874 and ATCC VR-740, respectively). The human HCV-OC43 respiratory coronavirus was provided to us by P. Talbot (IAF, Laval, Qc, Canada). The other coronavirus isolates were recovered from Québec herds experiencing clinical cases of Neonatal Calf Diarrhoea (NCD) during winter 1989 or typical outbreaks of WD during winters 1992 and 1993. All the BCV strains were propagated in HRT-18 cells and passaged not more than 5 times in the presence of $10 \mathrm{U} / \mathrm{ml}$ of bovine pancreatic trypsin ${ }^{9}$. The extracellular virions were purified from the supernatants of infected cell cultures by differential and isopycnic ultracentrifugation on sucrose gradients ${ }^{9,13}$. A rabbit hyperimmune serum was prepared against the prototype BCV-Meb strain according to immunization protocole described elsewhere ${ }^{9}$. Infectivity titers, and enzymatic activities were determined on purified BCV preparations, as previously described ${ }^{9}, 14$. The HA activity was determined on rat erythrocytes at $4^{\circ}$ and $37^{\circ} \mathrm{C}^{9}$, and the antigenic relationships between WD and NCD strains were evaluated using $\mathrm{VN}$ and HAI tests ${ }^{9}$. 
Cloning and sequencing of the HE genes of two Québec NCD isolates (BCQ.3 and BCQ.571) and one WD isolate (BCQ.2590), were also done as previously described ${ }^{15}$. Their complete nucleotide and predicted amino-acid sequences were compared with those of reference BCV-Mebus strain. Sequence analyses were performed using the MacVector 3.5 (International Biotechnologies) and GeneWorks 2.2 (IntelliGenetics Inc) programs.

\section{RESULTS AND DISCUSSION}

The NCD and WD isolates of BCV were successfully propagated in HRT-18 cells in the presence of $10 \mathrm{U} / \mathrm{ml}$ of trypsin. Their biological and serological characteristics are summarised in Table 1. On the basis of cytopathogenicity on HRT-18 cells, Québec strains could be classified into weak fusogenic (induced production of small syncytia), highly fusogenic (syncytia increased in number and size) leading to complete destruction of the cell sheets 3 to 4 days after infection, and non fusogenic but highly cytolytic (no syncytia but intense degenerescence of the monolayers).

The hemagglutination (HA) titers obtained with rat erythrocytes were quite similar for the WD and NCD isolates after 1 hour incubation at $4^{0} \mathrm{C}$ (results not shown). However a drastic drop in HA titers of WD isolates occurred if the incubation temperature was raised to $37^{\circ} \mathrm{C}$, whereas temperature did not seem to affect the HA activity of NCD isolates.

Although the Québec WD and NCD isolates were serologically indistinguishable from BCV-Meb strain by virus neutralisation (VN), 16 to 32 fold differences in HAI titer of the specific anti-BCV hyperımmune serum were obtained between the WD and the reference $\mathrm{BCV}-\mathrm{Meb}$ strain. The reference anti-BCV serum reacted with same HAI titers to all NCD 1solates tested, except BCQ.571 and BCQ.2070. No reactivity of the BCV hyperimmune

Table 1. Biological and serological characteristics of cell culture adapted-NCD and -WD bovine coronaviruses

\begin{tabular}{|c|c|c|c|c|c|c|c|c|}
\hline \multirow{2}{*}{$\begin{array}{l}\text { Viral } \\
\text { isolate }\end{array}$} & \multirow[b]{2}{*}{ Disease } & \multirow{2}{*}{$\begin{array}{c}\text { Type of } \\
\text { CPE }^{\mathrm{a}}\end{array}$} & \multirow{2}{*}{$\begin{array}{c}\text { Infectivity } \\
\text { titers }{ }^{b}\end{array}$} & \multicolumn{2}{|c|}{ Cross-reactivity $^{\mathrm{c}}$} & \multirow{2}{*}{$\begin{array}{l}\text { Acetyl- } \\
\text { esterase }^{d}\end{array}$} & \multicolumn{2}{|c|}{ RDE titer ${ }^{\mathrm{e}}$} \\
\hline & & & & $\mathrm{VN}$ & HAI & & Rooster & Rat \\
\hline BCQ 2439 & WD & $\mathrm{C}$ & 72 & 2560 & 80 & 3292 & 16 & 8 \\
\hline BCQ 2442 & WD & $\mathrm{C}$ & 72 & 2560 & 80 & 3193 & ND & $<2$ \\
\hline BCQ 2508 & WD & $\mathrm{C}$ & 87 & 1280 & 80 & 3089 & 4 & 64 \\
\hline BCQ 2590 & WD & $\mathrm{C}$ & 94 & 2560 & 80 & 0764 & 64 & 128 \\
\hline BCQ 7373 & WD & $\mathrm{C}$ & 87 & NT & 160 & 2151 & 64 & 256 \\
\hline BCQ 3 & NCD & B & 84 & 1280 & 1280 & 0492 & 32 & $<2$ \\
\hline BCQ 9 & $\mathrm{NCD}$ & $\mathrm{B}$ & 97 & 2560 & 1280 & 1826 & 16 & 2 \\
\hline BCQ 189 & NCD & $\mathrm{A}$ & 89 & 1280 & 1280 & 3388 & 64 & $<2$ \\
\hline BCQ 571 & NCD & $\mathrm{C}$ & 77 & 2560 & 80 & 3210 & 8 & $<2$ \\
\hline BCQ 20 & NCD & A & 75 & 1280 & 40 & 1782 & 2 & $<2$ \\
\hline BCQ 2070 & NCD & $\mathrm{C}$ & 79 & 2560 & 1280 & 1877 & 32 & $<2$ \\
\hline BCVMeb & NCD & A & 94 & 2560 & 1280 & 3155 & 8 & 2 \\
\hline
\end{tabular}

${ }^{a}$ On the basis of cytopathic changes induced in HRT-18 cells, Quebec BCV isolates could be classified into weak fusogenic (A), highly fusogenic (C), and non-fusogenic but highly cytolytıc (B) strains

${ }^{\mathrm{b}} \mathrm{TCID}_{50} \quad 50 \%$ tissue culture infective dose

${ }^{\mathrm{c}}$ Reciprocal of highest dilution of polyclonal ant1-BCV serum (Mebus strain) that inhibited $100 \mathrm{TCID}_{50}$ or 4 hemagglutınatıng units of virus WD winter dysentery, NCD neonatal calf diarrhoea, NT non tested ${ }^{\mathrm{d}}$ Optical density at $405 \mathrm{~nm}$ after $5 \mathrm{~min}$ of reaction with $1 \mathrm{mM}$ p-nitrophenyl acetate 
serum was demonstrated when tested against the heterologous hemagglutinating coronaviruses (HEV-67 and HCV-OC43).

To further investigate on the biological properties of WD isolates in comparison to NCD isolates, different viral functions were assessed on purified BCV isolates containing infectivities of $10^{7.2}$ to $10^{9.4} \mathrm{TCID}_{50} / \mathrm{mL}$ (Table 1). Although high variability was observed amongst the infectivity titers of the BCV strains tested, they appeared to possess similar AE activity with the exception of Québec isolates BCQ.3 and BCQ.2590 which possessed a weak AE activity. The RDE (receptor destructive enzyme) titers determined for WD strains with rat erythrocytes varied from 8 to 256 , but the RDE activity was minimal or not detectable for the NCD isolates. All the BCV tested demonstrated lower HA activity with rooster erythrocytes (results not shown) than with rat erythrocytes, but elution through RDE activity was detected with titers of 16 to 64 with rooster erythrocytes.

Previous studies suggested close resemblance between NCD and WD strains. The present results provide additional data on the biological and serological properties of these $\mathrm{BCV}$ isolates. As previously reported ${ }^{7}$, the WD isolates were highly fusogenic. They induced a severe cytopathic effect in comparison to the avirulent $\mathrm{BCV}$ strains. Interestingly two virulent BCV strains (BCQ.571 and BCQ.2070) behaved also as highly fusogenic strains. Changes in the amino acid sequences of the $\mathrm{S}$ glycoproteins between these two strains and the reference BCV-Meb strain were recently reported ${ }^{15}$. Whether these differences at the molecular level could be related to the BCV virulence remains to be elucidated. Our results could also differentiate between WD and NCD strains on basis of their interaction with different erythrocytes. Both NCD and WD isolates agglutinated rat erythrocytes with similar titers at $4^{\circ} \mathrm{C}$, but a drastic drop was noticed in the HA titers of WD isolates at $37^{\circ} \mathrm{C}$. This difference regarding HA activity could be related to receptor inactivation as demonstrated by the RDE activity of HE protein which was more effective in tests involving WD than NCD strains. The higher RDE activity could explain the high contagiousness of WD strains and the short duration of the syndrome in the affected herd. On the other hand, the difference in the RDE activity between rat and rooster erythrocytes could be due to a variation in receptor binding properties or to structural differences in the receptors between the species as it was already suggested ${ }^{14}$. If receptor binding and viral attachment to susceptible cells is attributed to the $\mathrm{S}$ glycoprotein ${ }^{16}$, the $\mathrm{AE}$ of the $\mathrm{HE}$ protein may play a role in virus release from infected cells and viral spread.

Since differences identified between WD and NCD isolates appeared to be associated to biological functions and antigenicity of their HE proteins, we investigated on a possible explanation at the molecular level. The HE genes of two Québec NCD (BCQ.3 and BCQ.571) and one WD (BCQ.2590) isolates, were cloned and sequenced. Their complete nucleotide and deduced amino-acid sequences were compared with those of the reference BCV-Meb strain.

At the nucleotide level, a high degree of similarity was demonstrated among Québec BCV isolates BCQ.3, BCQ.571 and BCQ.2590. The only variation that appeared consisted of 25 nucleotide substitutions which represented $5.8 \%$ of the entire HE gene sequence. Among these substitutions, 11 appeared to be specific to the WD isolate and the deduced amino acids sequence are interesting (results not shown). Three proline substitutions occurred between WD and the reference Mebus isolates. The first one is localized in the signal peptide (at aa 5) and the second one at aa 377. These two substitutions were already identified for the virulent BCV-LY138 strain ${ }^{17}$. The third substitution seemed to be specific to the WD isolate. It was localized (at aa 53) in the vicinity of the sequences of the putative esterase active domain (FGDS) which was conserved in all BCV strains analyzed.

Our results did not permit to identify major differences at the molecular level between WD and NCD associated strains. Whether the proline substitutions in HE protein gene could result in conformational changes ${ }^{18}$ causing an alteration in the viral interaction with surface 
receptors remain to be elucidated Further genetic characterisation of additional isolates from various geographical areas is necessary to determine the extent of variability at the genomic level

Monoclonal antibodies directed against WD strain BCQ 2590 were recently produced they were found to be able to differentiate between NCD and WD isolates using HAI tests Other studies consisting of identıfying their respective antigenic determinants or epitopes are presently in progress

\section{REFERENCES}

1 Dea S, Roy R S, Elazhary Y La diarrhee neonatale due au coronavirus du veau Une revue de litterature Can Vet J 1981,22 51-58

2 Durham P J K, Hassard L E, Armstrong K R, Naylor J M Coronavirus-associated diarrhoea (winter dysentery) in adult cattle Can Vet J 1989,30 825-827

3 McNulty M S, Bryson D G, Allan G M, Logan E F Coronavirus infection of the bovine respiratory tract Vet Microbiol 1984,9 425-434

4 Saif L J, Brock, K V Redman D R, Kohler E M Winter dysentery in darry herds electron microscopic and serological evidence for an association with coronavirus infection Vet Rec 1991,128 447-449

5 Campbell S G, Cookıngham C A The enigma of winter dysentery Cornell Vet 1978,68 423-441

6 Takahashı E, Inaba Y, Sato K, Ito Y, Kurocı H, Akashı H, Satoda K, Omorı T Epızootıc diarrhoea of adult cattle associated with a coronavirus-like agent Vet Microbiol 1980,5 151-154

7 Benfield D A, Saif L J Cell culture propagation of a coronavirus solated from cows with winter dysentery J Clin Microbiol 1990,28 1454-1457

8 Mebus C A, Stair E L, Rhodes M B , Twiehaus M J Neonatal calf diarrhoea propagation, attenuation, and characteristics of a coronavirus-like agent Am J Vet Res 1973, 34 145-150

9 Dea S, Verbeek A J, Tijssen P Antigenic and genomic relationships between turkey and bovine enteric coronavirus J Virol 1990,64 3112-3118

10 Cavanagh D, Brian D A, Enjuanes L, Holmes K V, La1 M M C, Laude H, Siddell S G, Spaan, W, Taguchı F, Talbot $\mathrm{P}$ Recommendation of the coronavirus study group nomenclature of the structural proteins, mRNAs and genes of coronaviruses Virology $1990 \quad 176$ 306-307

11 Reynolds D J, Debney T G , Hall G A, Thomas, L H, Parsons K R Studıes on the relatıonship between coronaviruses from the intestınal and respiratory tracts of calves Arch Virol 1985,85 71-83

12 Michaud L, Dea S Characterization of monoclonal antibodies to bovine enteric coronavirus and antigenic variations among Quebec isolates Arch Virol 1993,131 455-465

13 Dea S , Roy R S, Begın M E Bovine coronavirus isolation in contınuous cell lines Amer J Vet Res 1980,41 30-38

14 Storz J Zhang X M, Rott R Comparıson of hemaglutınatıng, receptor destroyıng and acetylesterase activities of avirulent and virulent bovine coronavirus strains Arch Virol 1992,125 193-204

15 Rekık M R, Dea S Comparatıve sequence analysıs of a polymorphic region of spıke protein gene of bovine coronavirus isolates Arch Virol 1994,135 319-331

16 Spaan W, Cavanagh D, Horzınek M C Coronavıruses structure and genome expression J Gen Virol $1988,692939-2952$

17 Zhang X, Kousoulas K G, Storz J The hemagglutının/esterase glycoproteın of bovine coronavirus sequence and functional comparısons between virulent and avirulent strains Virology 1991,185 847-852

18 Yaron A, Naider F Prolıne-dependent structural and biological properties of peptide and proteins Critical Rev Biochem Mol Biol 1993,28 31-81 